\title{
Assessment of Knowledge, Perception and Attitude of Clinical Radiography Students on Ebola Virus Disease at University Of Maiduguri
}

\author{
${ }^{1}$ Nwobi I.C., ${ }^{1}$ Obinna OS. ${ }^{1}$ Obotiba A.D., ${ }^{1}$ Abubakar A., ${ }^{1}$ Abubakar M.G, \\ ${ }^{1}$ Luntsi G., ${ }^{1}$ Nkubli F.B., ${ }^{1}$ Njiti M., \\ ${ }^{I}$ Department of Radiography, College of Medical Sciences, University of Maiduguri, Nigeria
}

\begin{abstract}
Objective: To determine the clinical radiography student's level of knowledge, perception, and attitudes, towards Ebola Virus Disease.

Methods: A cross-sectional survey was conducted using eligible and consented 80 respondents who were radiography students in their clinical phase with 30-item questionnaires, validity and reliability were obtained. The data was analyzed using Epi info version 3.5.4 where descriptive statistics such as frequency and percentage were obtained.

Results: Findings show that $8.8 \%(n=7)$ of respondents are below the age of 20 years, $72.5 \%(n=58)$ are between 21-30 years of age while 18\% $(n=15)$ are between 31-40 years. Generally, respondents good high knowledge on the nature $87.5 \%(n=70)$ and fatal rate $93.7 \%(n=75)$ of Ebola disease, with majority of them being aware of the outbreak. Positive perception was noted among respondents and $58.8 \%(n=47)$ indicated that they would not participate in Radiologic procedures involving Ebola patients.

Conclusion: In general, there was good knowledge, adequate perceptions and positive attitude towards the nature, incubation period, and mortality rate of Ebola virus disease among radiography students. However, high numbers lack knowledge on the preventive measures and treatments. The study recommends further improvement on knowledge, perception and attitude of radiography students.
\end{abstract}

Key Words: Knowledge, Perception, Attitude, and Ebola virus disease.

\section{Introduction}

Ebola virus disease (EVD) is a viral hemorrhagic fever that is highly transmissible and all too often rapidly fatal. In 1976, Ebola (named after the Ebola River in Zaire) first emerged in Sudan and Zaire [1]. The first outbreak of Ebola (Ebola-Sudan) infected over 284 people, with a mortality rate of 53\%. A few months later, the second Ebola virus emerged from Yambuku, Ebola-Zaire (EBOZ). This outbreak produced the highest mortality rate of any of the Ebola viruses (88\%), which infected 318 people [2]. Despite the tremendous effort of experienced and dedicated researchers, Ebola's natural reservoir was never identified [3]. The third strain of Ebola, Ebola Reston (EBOR), was first identified in 1989 when infected monkeys were imported into Reston, Virginia, from Mindanao in the Philippines [4]. Fortunately, the few people who were infected with EBOR never developed Ebola hemorrhagic fever (EHF) [5]. The last known strain of Ebola, Ebola Cote d'Ivoire (EBO-CI) was discovered in 1994 when a female etioologist performing a necropsy on a dead chimpanzee from the Tai Forest, Cote d'Ivoire, accidentally infected herself during the necropsy [6]. Recent outbreaks in West Africa reveal that this infection has the potential to be transmitted worldwide [2]. Also, from the advent of this virus till date, there are several cases of its outbreak across West Africa in which Nigeria was involved. Ebola virus disease is known to cause severe diarrhea, electrolyte disturbances and other major end-organ dysfunction. Hence, Personal protective equipment (PPE) is necessary for all patient contact, and enhanced PPE is required for all aerosol-generating medical procedures in which radiographers are not exception [7]. In addition, the researchers have noted misconception on the nature, transmission, diagnosis, treatment and prognosis of Ebola virus disease among clinical radiography students. Thus Knowledge, perception and attitude of radiography students towards this disease is unknown. Therefore, this present study is aimed at determining the level of knowledge, Perception and Attitude towards Ebola disease by radiography students in clinical phase and association with level of study.

\section{Materials And Methods}

The research design adopted for this study is a descriptive survey method. The population for the study included clinical radiography students ranging from 300 level to 500 level. A quota sampling technique used to administer the questionnaires to eighty (80) students and the whole questionnaires were retrieved completed. The questionnaire was a self-administered semi-structured consisting of four (4) sections: section A contains 
basic information on bio data of students, while section B, C, D, E, of the questionnaires had questions sub divided into parts covering awareness of Ebola virus disease, knowledge, perception and attitude of radiography students on Ebola virus disease respectively. The questionnaire was subjected to face and content validity with a pilot study carried out on 10 students from the department to determine its reliability. Necessary corrections and modifications were made to the questionnaire.

Data was collected by the researcher and assistants who had training on the objectives of the study and on the data collection techniques. The data was analyzed using Epi info version 3.5.4 and were presented in: tables, frequencies, percentages and charts. Clearance to conduct the research was obtained from the ethical committee in radiology department at University of Maiduguri Teaching Hospital. For each class visited, an informed consent was obtained from eligible respondents. Respondents were assured that the information obtained from them was for purposes of the study and was to be treated with utmost confidentiality. After this, the questionnaires were administered.

\section{Results}

The result shows that there are $53.3 \%(\mathrm{n}=16)$ males and $46.7 \%(\mathrm{n}=14)$ female respondents of 300 level, $56 \%(\mathrm{n}=14)$ males and $44 \%(\mathrm{n}=11)$ female respondents of 400 level and $28 \%(\mathrm{n}=12)$ males and $52 \%(\mathrm{n}=13)$ female respondents of 500 level. Findings revealed that $16.7 \%(n=5)$ the of respondents are below the age of 20 years in 300 level and $83.3 \%(n=25)$ are within the age range of 21-30 years. Eight percent $(n=2)$ of 400 level respondents are below the age of 20 years and $84 \%(n=21)$ are between 21-30 years of age while $8 \%(n=2)$ are between 31-40 years. About 48\% (n=12) respondents in 500 level are within the age range of 21-30 years and $52 \%(n=13)$ within the age of 31-40 years.

Table 1:Frequency and percentage distribution of respondents on the knowledge of EVD Options

\begin{tabular}{|c|c|c|c|c|c|c|c|c|c|c|c|c|}
\hline \multirow{2}{*}{$\begin{array}{l}\text { Questions } \\
\text { on } \\
\text { knowledge } \\
\text { of EVD }\end{array}$} & \multicolumn{3}{|c|}{ Present level of study } & \multicolumn{3}{|c|}{ Present level of study } & \multicolumn{3}{|c|}{ Present level of study } & \multicolumn{3}{|c|}{ Composite } \\
\hline & \multicolumn{3}{|c|}{$\begin{array}{l}300 \text { Level } \\
\text { Frequency (Percentage\%) }\end{array}$} & \multicolumn{3}{|c|}{$\begin{array}{l}400 \text { Level } \\
\text { Frequency (Percentage\%) }\end{array}$} & \multicolumn{3}{|c|}{$\begin{array}{l}500 \text { Level } \\
\text { Frequency (Percentage\%) }\end{array}$} & \multirow[b]{2}{*}{ Viral } & \multirow[b]{2}{*}{ Bacterial } & \multirow[b]{2}{*}{$\begin{array}{l}\text { Don't } \\
\text { Know }\end{array}$} \\
\hline \multirow{2}{*}{$\begin{array}{l}\text { What kind } \\
\text { of disease } \\
\text { is Ebola? }\end{array}$} & Viral & Bacterial & $\begin{array}{l}\text { Don't } \\
\text { Know }\end{array}$ & Viral & Bacterial & $\begin{array}{l}\text { Don't } \\
\text { Know }\end{array}$ & Viral & Bacterial & $\begin{array}{l}\text { Don't } \\
\text { Know }\end{array}$ & & & \\
\hline & $26(86.7)$ & $3(10)$ & $1(3.3)$ & $21(84)$ & $2(8)$ & $2(8)$ & $23(92)$ & $1(4)$ & 1(4) & $70(87.5)$ & $6(7.5)$ & $4(5)$ \\
\hline \multirow{2}{*}{$\begin{array}{l}\text { What is the } \\
\text { incubation } \\
\text { period of } \\
\text { Ebola? }\end{array}$} & 21 days & 31 days & $\begin{array}{l}16 \\
\text { days }\end{array}$ & $\begin{array}{l}21 \\
\text { days }\end{array}$ & 31 days & 16 & $\begin{array}{l}21 \\
\text { days }\end{array}$ & 31 days & $\begin{array}{l}16 \\
\text { days }\end{array}$ & 21 days & 31 days & $\begin{array}{l}16 \\
\text { days }\end{array}$ \\
\hline & $29(96.7)$ & $1(3.3)$ & - & $23(92)$ & - & $2(8)$ & $23(92)$ & 1(4) & $1(4)$ & $75(93.7)$ & $2(2.5)$ & $3(3.8)$ \\
\hline \multirow[b]{2}{*}{$\begin{array}{l}\text { What is the } \\
\text { mortality } \\
\text { rate of } \\
\text { Ebola } \\
\text { disease? }\end{array}$} & $88 \%$ & $25 \%$ & $16 \%$ & $88 \%$ & $25 \%$ & $16 \%$ & $88 \%$ & $25 \%$ & $16 \%$ & $88 \%$ & $25 \%$ & $16 \%$ \\
\hline & $19(63.3)$ & $6(20)$ & $5(16.7)$ & 19(76) & $5(20)$ & $1(4)$ & $18(72)$ & $2(8)$ & $2(8)$ & $56(70)$ & $13(16.3)$ & $8(10)$ \\
\hline \multirow{2}{*}{$\begin{array}{l}\text { Do you } \\
\text { accept that } \\
\text { Ebola can } \\
\text { be } \\
\text { prevented } \\
\text { by } \\
\text { avoiding } \\
\text { contacts } \\
\text { with } \\
\text { blood/body } \\
\text { fluid? }\end{array}$} & Yes & No & $\begin{array}{l}\text { I } \\
\text { Don't } \\
\text { know }\end{array}$ & Yes & No & $\begin{array}{l}\text { I } \\
\text { Don't } \\
\text { know }\end{array}$ & Yes & No & $\begin{array}{l}\text { I } \\
\text { Don't } \\
\text { know }\end{array}$ & Yes & No & $\begin{array}{l}\text { I } \\
\text { Don't } \\
\text { know }\end{array}$ \\
\hline & $26(86.6)$ & $2(6.7)$ & $2(6.7)$ & $23(92)$ & $1(4)$ & $1(4)$ & $23(92)$ & - & $2(8)$ & $72(90)$ & $72(90)$ & $5(6.3)$ \\
\hline
\end{tabular}

Table 2:Frequency and percentage distribution of respondents on the perception of EVD Options

\begin{tabular}{|c|c|c|c|c|c|c|c|c|c|c|c|c|}
\hline \multirow{2}{*}{$\begin{array}{l}\text { Questions on } \\
\text { perception of } \\
\text { EVD }\end{array}$} & \multirow{2}{*}{\multicolumn{3}{|c|}{$\begin{array}{l}\text { Present level of study } \\
300 \text { Level } \\
\text { Frequency (Percentage\%) }\end{array}$}} & \multirow{2}{*}{\multicolumn{3}{|c|}{$\begin{array}{l}\text { Present level of study } \\
400 \text { Level } \\
\text { Frequency } \\
\text { (Percentage\%) }\end{array}$}} & \multirow{2}{*}{\multicolumn{3}{|c|}{$\begin{array}{l}\text { Present level of study } \\
500 \text { Level } \\
\text { Frequency } \\
\text { (Percentage\%) }\end{array}$}} & \multicolumn{3}{|c|}{ Composite } \\
\hline & & & & & & & & & & \multirow[b]{2}{*}{ Yes } & \multirow[b]{2}{*}{ No } & \multirow[b]{2}{*}{$\begin{array}{l}\text { Don't } \\
\text { Kno } \\
\text { w }\end{array}$} \\
\hline \multirow{2}{*}{$\begin{array}{l}\text { Do you believe } \\
\text { that EVD can } \\
\text { be cured via } \\
\text { salt bathing } \\
\text { therapy? }\end{array}$} & Yes & No & $\begin{array}{l}\text { Don't } \\
\text { Know }\end{array}$ & Yes & No & $\begin{array}{l}\text { Don't } \\
\text { Kno } \\
\text { w }\end{array}$ & Yes & No & $\begin{array}{l}\text { Don't } \\
\text { Know }\end{array}$ & & & \\
\hline & $4(13.3)$ & $\begin{array}{l}26(86.7 \\
)\end{array}$ & - & - & $\begin{array}{l}24(96 \\
{ }^{2}\end{array}$ & 1(4) & $4(16)$ & $\begin{array}{l}20(80 \\
)^{2}\end{array}$ & 1(4) & $8(10)$ & $\begin{array}{l}70(87.5 \\
)^{2}\end{array}$ & $2(2.5)$ \\
\hline $\begin{array}{lr}\begin{array}{l}\text { Would } \\
\text { regard }\end{array} & \text { you } \\
\text { bathing } \\
\text { therapy as a } \\
\text { vaccine for } \\
\text { EVD? }\end{array}$ & - & $\begin{array}{l}28(93.3 \\
)\end{array}$ & $2(6.7)$ & $1(4)$ & $\begin{array}{l}24(96 \\
)\end{array}$ & - & $3(12)$ & $\begin{array}{l}22(88 \\
)\end{array}$ & - & $4(5)$ & $\begin{array}{l}74(92.5 \\
)\end{array}$ & $2(2.5)$ \\
\hline
\end{tabular}


Assessment Of Knowledge, Perception And Attitude Of Clinical Radiography Students On Eb...

\begin{tabular}{|l|l|l|l|l|l|l|l|l|l|l|l|l|}
\hline $\begin{array}{l}\text { Do you believe } \\
\text { it can be } \\
\text { treated } \\
\text { medically? }\end{array}$ & $\begin{array}{l}28(93.3 \\
\text { ) }\end{array}$ & - & $2(6.7)$ & $23(92$ & $1(4)$ & $1(4)$ & $22(88$ & $1(4)$ & $2(8)$ & $73(91.3$ & $2(2.5)$ & $5(6.2)$ \\
\hline $\begin{array}{l}\text { Do you accept } \\
\text { that Ebola can } \\
\text { be treated } \\
\text { successfully by } \\
\text { traditional } \\
\text { healers? }\end{array}$ & $2(6.7)$ & $20(66.6$ & $8(26.7)$ & $4(16)$ & $18(27$ & $3(12)$ & $4(16)$ & $14(56$ & $7(28)$ & $10(12.5$ & $52(65)$ & $18(22$ \\
\hline $\begin{array}{l}\text { Do you accept } \\
\text { that Ebola can } \\
\text { be treated } \\
\text { successfully by } \\
\text { spiritual } \\
\text { healers? }\end{array}$ & 1(3.3) & $16(53.4$ & $13(43.3$ & $7(28)$ & $12(48$ & $6(24)$ & $2(8)$ & $12(48$ & $11(44$ & $10(12.5$ & $40(50)$ & $30(37$ \\
\hline $\begin{array}{l}\text { Do you believe } \\
\text { EVD can be } \\
\text { prevented by } \\
\text { avoiding } \\
\text { funeral or } \\
\text { burial rituals } \\
\text { requiring } \\
\text { handling the } \\
\text { body of } \\
\text { someone who } \\
\text { died of Ebola? }\end{array}$ & $19(63.4$ & $10(33.3$ & $1(3.3)$ & $13(52$ & $5(20)$ & $7(28)$ & $11(44$ & $7(2.8)$ & $7(28)$ & $43(53.8$ & $22(27.5$ & $15(18$ \\
\hline
\end{tabular}

Table 3:Frequency and percentage distribution of respondents' towards patients with EVD Options

\begin{tabular}{|c|c|c|c|c|c|c|c|c|c|c|c|c|}
\hline \multirow{2}{*}{$\begin{array}{lc}\text { Questions } & \text { on } \\
\text { perception } & \text { of } \\
\text { EVD } & \end{array}$} & \multicolumn{3}{|c|}{ Present level of study } & \multirow{2}{*}{\multicolumn{3}{|c|}{$\begin{array}{l}\text { Present level of study } \\
\text { 400 Level } \\
\text { Frequency } \\
\text { (Percentage\%) }\end{array}$}} & \multirow{2}{*}{\multicolumn{3}{|c|}{$\begin{array}{l}\text { Present level of study } \\
500 \text { Level } \\
\text { Frequency } \\
\text { (Percentage\%) }\end{array}$}} & \multicolumn{3}{|c|}{ Composite } \\
\hline & \multicolumn{3}{|c|}{$\begin{array}{l}300 \text { Level } \\
\text { Frequency (Percentage\%) }\end{array}$} & & & & & & & & & \\
\hline \multirow{2}{*}{$\begin{array}{l}\text { Would you } \\
\text { participate in a } \\
\text { procedure } \\
\text { involving an } \\
\text { Ebola case? }\end{array}$} & Yes & No & $\begin{array}{l}\text { Don't } \\
\text { Know }\end{array}$ & Yes & No & $\begin{array}{l}\text { Don't } \\
\text { Know }\end{array}$ & Yes & No & $\begin{array}{l}\text { Don't } \\
\text { Know }\end{array}$ & Yes & No & $\begin{array}{l}\text { Don't } \\
\text { Know }\end{array}$ \\
\hline & $9(30)$ & $20(66.7)$ & $1(3.3)$ & $4(16)$ & $12(4)$ & 9(36) & $4(16)$ & $15(60)$ & $6(24)$ & $17(21.3)$ & $47(58.8)$ & $16(20)$ \\
\hline 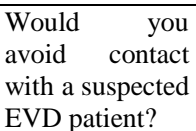 & $23(76.7)$ & $4(13.3)$ & $7(23.3)$ & $23(92)$ & - & $2(8)$ & 19(7) & $2(8)$ & $4(16)$ & $65(81.3)$ & $6(7.5)$ & $53(66.3)$ \\
\hline
\end{tabular}

\section{Discussion}

Generally there are high knowledge on the nature, $87.5 \%(n=70)$ and fatal rate, $93.7 \%(n=75)$ of Ebola disease among the respondents and almost everybody is aware of the outbreak which concurs with the study carried out by Adongo et al., was 94\% [8]. This maybe as a result of various enlightenment programmes from health ministries, religious bodies, schools and social media that were used to sensitize and educate the general public towards Ebola virus disease.

However, the result shows that 300 level respondents have high knowledge with $96.7 \%(n=29)$ on the incubation period of Ebola, probably because they were less engaged with much school activities at the time of its outbreak and had enough time to visit websites, listen to radio, watch television in the search for more knowledge towards Ebola virus disease and less knowledge of $92.0 \%(n=23)$ was recorded on both 400 and 500 levels respondents, this may be due to high course load to 500 level respondents as compared to 300 level students so they have less time to listen to radio, television and other significant social media.

High level of knowledge was noted on the mortality rate of Ebola with 300 level respondents with $63.3 \%(n=19)$ and poor knowledge with 500 level respondents $17.0 \%(n=18)$, which may be as a result of gap in knowledge to obtain current information. The knowledge on mode of transmission of Ebola virus disease in 300 level was high $92 \%(n=26)$, probably because they were less occupied by academic work load and had time to visit internet to gain more resourceful information and low in both 400 level and 500 level respondents with $86.6 \% \quad(n=23)$ each perhaps they had less time to visit internet because they were mostly preoccupied by high academic work load and were seriously tied to clinical posting.

The result shows that 300 level respondents have the highest knowledge with $86.75(n=26)$ and less knowledge were obtained in 500 level respondents with $80 \%(n=20)$ based on the misconception that Ebola could be cured through salt bathing therapy, the high knowledge recorded could be attributed to the various reeducation and enlightenment that went across the fingers of the internet, other social media, religious bodies and most of them had time to partake in the gain of information shared towards Ebola virus disease as compared 
to 400 level and 500 level respondents that were always tied down with clinical posting and had much academic work load and only got information from friends and families that called through mobile phone in which information on salt bathing therapy lingered in 27 January 2014 here in Nigeria. The result shows that adequate knowledge were obtained from 300 level respondents with $93.3 \%(\mathrm{n}=28)$ towards salt bathing as a vaccine for Ebola disease, their good knowledge could be as a result of their follow up to gain more information from a resourceful personnel and social media. Against salt therapy as a vaccine for Ebola disease and less knowledge were obtained from 500 level respondents, possibly because they lack knowledge of the availability of the site that could re-educate them or had less time to visit websites or other resourceful source of information. In 300 level respondents, $93.3 \%(\mathrm{n}=28)$ believe that Ebola can be treated medically which could possibly be as a result of re-education from various resourceful social media, health ministries, religious bodies. $88 \%(\mathrm{n}=27)$ believes in 500 level respondents that Ebola could be treated medically which shows their strong hold that medically, most viral infectious diseases could be successfully treated medically while $4 \%(n=1)$ of the 400 level respondents rejected such concept which were likely due to gap in knowledge towards medical treatment of Ebola virus disease. The result uncovers that $66.65(\mathrm{n}=20)$ of 300 level respondents rejected that Ebola cannot be treated successfully by a traditional healer, probably because of their knowledge on the available means of Ebola virus disease while $65 \%(n=14)$ of 500 level respondents rejected such concept, possibly because they have good knowledge of medical treatment of Ebola and do not believe that traditional healing of Ebola disease as it could not be medically and physiologically linked. The result as well reveals that $50 \%(\mathrm{n}=40)$ of the total respondents do not believe that Ebola could be treated successfully by the spiritual healers as it lacks correlation between medical, physiological system and spiritual power while $12.5 \%(\mathrm{n}=10)$ accept the opinion, possibly because of their faith in spiritual healings. The result shows that $53.85(n=43)$ of the total respondents believe that the disease could be prevented by avoiding funeral or burial rituals that requires handling the body of someone who has died from Ebola, this were likely due to information received from trusted health ministries while $12.5 \%(\mathrm{n}=10)$ accepted the opinion, perhaps due to gap in information received by health ministries while 7\% $(\mathrm{n}=15)$ said they do not know probably because they are not sure if Ebola could be prevented by avoiding funeral or burial rituals that require handling the body of someone who has died from Ebola disease

The result uncovers that $21.35(\mathrm{n}=17)$ would participate in procedure involving an Ebola case patient, this could be as a result of their strong feeling of empathy rather than sympathy, although individual responses may not always align with the actual practices while $58.8 \%(n=47)$ of the respondents said that they would not participate, probably because of their believe that no one temper with an Ebola case patient and get away with it being free of Ebola infection. The research shows that $81.3 \%(n=65)$ would avoid contact with a suspected Ebola patient because of the fear of contracting the disease while $66.3 \%(n=53)$ reported saying "I don't know" probably, their response remains ambiguous until they are informed of any proximity of a suspected Ebola case patient to decide either to stay or run for their lives and properties, this attitude is in line with what is obtainable in the developed world. This study is limited by the fact that analysis was done based on respondent's responses and some may not have given sincere responses.

\section{Conclusion}

In general, there was good knowledge, adequate perceptions and positive attitude towards the nature, incubation period, and mortality rate of Ebola virus disease among radiography students with highest knowledge obtained in the 300 level class. However, high numbers lack knowledge on the preventive measures and treatments. The study recommends further improvement on knowledge, perception and attitude of radiography students.

\section{References}

[1]. Peters CJ. An Introduction to Ebola: The Virus and the Disease. Journ. Infect. Dis. 2014; 179 (1):Pp.ix-xvi. Doi:http://dx.doi.org/10.1086/514322

[2]. WHO Statement on the Meeting of the International Health Regulations Emergency Committee Regarding the 2014 Ebola Outbreak in West Africa. Available at[http://www.who.int/mediacentre/news/statements/2014/ebola-20140808/en/] [Accessed Oct., 2015]

[3]. Pattyn S., Van Der Groen G., Jacob W., Piot P. Isolation of Marburg-like Virus from a Case of Haemorrhagic Fever in Zaire. Lancet. 2013; 1:Pp.573-574

[4]. Kuiken T., Fouchier RA, Schutten M., Rimmelzwan GF., Van-Amerongen G., Van-Riel., Laman JD, De-Jong T., Van-Doornum G., Lim W., Ling AE., Chan PK., Tam JS., Zambon MC., Gopal R., Drosten C., Van Der Werf., Escriou N., Manuguerra JC, Stohr K., Peiris JS., Osterhaus AD. Newly discovered coronavirus as the primary cause of severe acute respiratory syndrome. Lancet. 2003;362(9380):Pp.263-270

[5]. Kondekar RR., Meshram SM., Gohane SA. A Review on Ebola Virus. IAJPR. 2015; 5(1):Pp.277-284

[6]. Saeidnia S., and Abdollahi. Haemorrhagic fever: Current outbreak and progresss in finding a cure. Journal of Pharmacitical Sciences. 2014 DOI: 10.1186/s40199-014-0070-9

[7]. Rouquet P., Froment JM., Berjemo M., Kilbourn A., Karesh W et al. Wild Animal Mortality Monitoring and Human Ebola Outbreaks, Gabon and Republic of Congo. Emerg. Infect. Dis. 201; 11:Pp283-290

[8]. Adongo PB, Tabong PT, Asampong E, Ansong J, Robalo M, and Adanu RM. Beyond Knowledge and Awareness: Addressing Misconceptions in Ghana's Preparation Towards an Outbreak of Ebola Virus Disease. PLOS. 2016; DOI: 10.1371/journalpone.0149627 